\title{
Identifying Genital Hygiene Behaviours of Pregnant Women in Rural and Urban Regions: A Cross-Sectional Study
}

\author{
Sibel Seker ${ }^{1}$ (D), Funda Citil Canbay ${ }^{2}$ (D), Nasim Firouz ${ }^{1}$ (D) Ceylan Cesur $^{1}$ (D) \\ ${ }^{1}$ Aydın Adnan Menderes University, Health Science Faculty, Aydın, Turkey. \\ ${ }^{2}$ Atatürk University, Faculty of Health Sciences, Erzurum, Turkey. \\ Correspondence Author: Funda Citil Canbay \\ E-mail: midwifefunda23@gmail.com
}

Received: $07.01 .2020 \quad$ Accepted: 14.10 .2020

\begin{abstract}
Objective: The research was done to identify the genital hygiene behaviors pregnant women in rural and urban regions.

Methods: This research was done in analytical cross-sectional design at a maternity and children hospital in Aegean Region between April 15-October 2019. 278 pregnant women, who applied for follow-up and accepted to participate in the research, were included in the research. The data were collected through personal information form and Genital Hygiene Behavior Inventory. Descriptive statistics, chi-square test, Mann Whitney $U$ test and Kruskal Wallis test were used in data analysis. Significance was accepted as $p<0.05$.

Results: It was identified that $26.9 \%$ of pregnant women in rural regions were primary school graduate and $44.4 \%$ were secondary school graduate. It was found that $32.4 \%$ of pregnant women living in urban regions were high school graduate and $31.2 \%$ had bachelor's degree. A statistically significant relationship was identified between educational status and genital hygiene behaviors of pregnant women $(p<0.05)$. Depending on their living places, Genital Hygiene Behavior Inventory mean score was calculated as $77.98 \pm 12.19$ those living in rural regions and $81.29 \pm 11.22$ for those living in urban regions. It was found that Genital Hygiene Behavior Inventory levels of pregnant women living in urban regions was higher than those living in rural regions at a statistically significant level $(p<0.05)$.

Conclusion: It was identified that living place, educational status, employment status, age status and marriage year affected genital hygiene behavior. it is suggested that health professionals provide genital hygiene training to the pregnant women living in rural regions and with a low level of income through protective and preventive approach.

Keywords: Pregnancy, Genital Hygiene, Rural, Urban, Reproductive health.
\end{abstract}

\section{INTRODUCTION}

Genital hygiene behaviors are self-care practices that individuals gain through their belief, ways of healthy life and hygiene habits. These practices differ among individuals. This difference stem from individuals' different life styles, culture and socio-economic features. Genital hygiene behaviors, like all hygiene behaviors, should converted into a form of behavior and should be provided individuals as a learned behavior $(1,2)$.

It is known that women are more prone to genital infections in comparison with men due to their anatomy. Genital hygiene behavior at an undesired level can generally lead to diseases which abnormal vaginal discharge, malodor and genital infections cause (3-5). Most women have problems about genital infections, are open to reservoirs and become more sensitive due to pregnancy. Urinary tract infections and vaginal infections occur more often because of the physical and mental changes especially experienced in pregnancy. It is seen that these infections cause negative pregnancy results like preterm labor, recurrent abortus and abortion based on abortus (6-8). In general terms; activities like using flexible and bleeding underclothes, changing underclothes daily, changing sanitary pads frequently, doing perineal cleaning top-down, keeping perineal area dry, avoiding from vaginal douching and washing hands before and after using the toilet are accepted as positive hygiene behaviors (9-13).

It is important to identify the genital hygiene habits of pregnant women throughout pregnancy in terms of determining those needing consultancy about genital hygiene habits and getting genital infections under control. The studies carried out in Turkey about genital hygiene behaviors are at a limited level and it was identified that as the education and income level increase, positive reproductive health attitudes increase $(14,15)$. As genital hygiene behaviors are shaped depending on different environmental factors, socioeconomic status and cultural factors, identifying genital hygiene behaviors of pregnant women living in rural and urban regions. Therefore, 
the research aimed to identify genital hygiene behaviors of pregnant women in rural and urban regions. In line with this aim, answers are sought for the questions below: "What is the genital hygiene behavior level of pregnant women in rural and urban regions?" and "What are the factors affecting genital hygiene behaviors of pregnant women in rural and urban regions?"

\section{METHODS}

\subsection{Type, place and time of the study}

The analytical cross-sectional research was carried out at maternity policlinics of a maternity and children hospital in Aegean Region between April 15-October 2019.

\subsection{Participants}

The research population included pregnant women applying to Ministry of Health Aydın Maternity and Children Hospital Maternity Policlinics for follow-up. This hospital was chosen due to the fact that it is convenient for the research purpose and all the pregnant women living in the rural and urban areas apply to it. Therefore, it was aimed to identify the difference between living place and genital hygiene behaviors. The number of pregnant women included in the research sample was identified as 239 at least through sampling method for unknown universe. In case of a loss, 275 pregnant women were invited to participate in the research. Selection of research sampling was done in accordance with the simple random numbers table. The participants were identified through random sampling method and all pregnant women, who were suitable to the research criteria and accepted to participate in the study, were taken into the scope of the study. When a randomly selected pregnant woman did not meet the criteria, the next pregnant woman was included in the study.

Four pregnant women did not accept to participate in the study and two pregnant women were excluded as they were illiterate. Six pregnant women were not taken in the scope of study totally. The pregnant women who were suitable to the research criteria were invited to the research in order. In terms of living place, 108 pregnant women were living in rural regions and 170 women were residing in urban regions. The study was completed with 278 pregnant women. The pregnant women residing in a village were allocated as rural and those living in a town or city were assigned to urban group. The data gathered from the rural and urban regions were evaluated and reported (Figure 1). The pregnant women, who were over 18, could understand Turkish, could speak, read and write in Turkish, were primary school graduate at least, did not have any psychological problem which could prevent filling the question form and were willing to participate in the study, were included in the study. Those, who had a psychological problem and did not fill the form completely, were excluded from the study.

\subsection{Data Collection Tools}

The data collection process started with the pregnant women taken into the study scope in accordance with the number of sampling. The pregnant women were filled the "Personal Information Form" and "Genital Hygiene Behavior Inventory". Those, who came to a state hospital in Aegean Region of Turkey for follow up, were informed about the research and were invited to participate in the research. The data were collected through questionnaire form and face-toface interview technic. Filling the questionnaire form took around 10-15 minutes.

\subsubsection{Personal Information Form}

It included 22 questions. It was prepared by the researchers for the purpose of collecting data about socio-demographic, obstetrical and gynecological features of pregnant women based on the literature (9-12).

\subsubsection{Genital Hygiene Behavior Inventory (GHBI)}

It is a four point Likert inventory consisting of 27 questions. The validity and reliability of the inventory was done by Ege and Eryılmaz (16). 1 point was given for the response "never", 2 points were given for the response "sometimes", 3 points were given for the response "usually" and 4 points were given for the response "always" in positive questions. Negative questions (numbered 17, 26 and 27) were graded reversely. The lowest score which can be gained is 27 and the highest score is 108 from GHBI. The score received from GHBI shows the level of genital hygiene behavior and as the total score increases, the genital hygiene behaviors reach to the desired level. It has single dimension and includes questions about practices of general hygiene, menstrual hygiene, toilet hygiene and genital hygiene. Its Cronbach's Alpha coefficient was $\alpha: 0.86$. It was calculated as $\alpha: 0.78$ in this research.

\subsection{Data Analysis}

Kolmogorow-Smirnov test, Shapiro-Wilk test, descriptive analysis, Mann Whitney $U$ test and Kruskal Wallis test were used in data analysis. Statistical significance level was accepted as $p<0.05$ in the research.

\subsection{Ethical Dimension of the Research}

Informed consent was received from the participant pregnant women by informing them about the research before starting to collect data. Ethical principles, including "the principle of privacy and privacy protection" with the statement that their data would be kept secret and "the principle of respect for autonomy" with the inclusion of people who were volunteer to participate in the research, were performed. Records about volunteers' identities were protected based on the related legislation provisions in a manner that would respect to private life and confidentiality rules. Helsinki declaration was honoured throughout the research. Ethics 
committee approval with the protocol number 2019/017 was received from Aydın Adnan Menderes University
Faculty of Health Sciences Noninvasive Chairmanship (Number:92340882-050.04.04./22405).

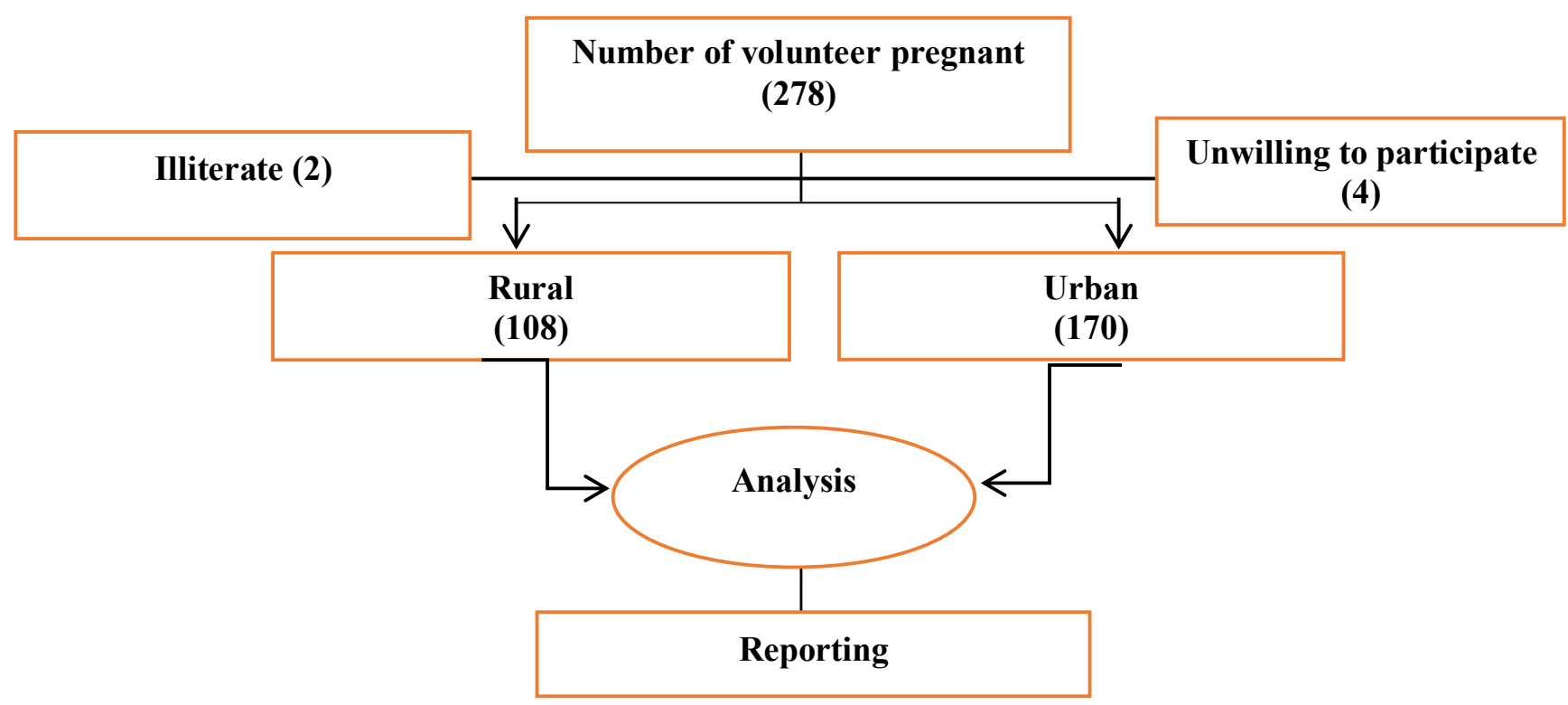

Figure 1. The process of research

\section{RESULTS}

It was identified that while $26.9 \%$ of pregnant women in rural regions were primary school graduate and $44.4 \%$ were secondary school graduate, $32.4 \%$ of pregnant women in urban regions were high school graduate and $31.2 \%$ had a bachelor's degree. A statistically significant relationship was found between education status and genital hygiene behaviors of pregnant women $(\mathrm{p}<0.05) .12 \%$ of pregnant women residing in rural regions and $28.2 \%$ of those residing in urban regions stated that they had an income-generating work. A statistically significant relationship between working status and genital hygiene behaviors of pregnant women was found $(p<0.05)$. Age average of pregnant women living in rural regions was $26.06 \pm 5.83(17-41)$ and that of those living in urban regions was $27.86 \pm 5.27(18-40)$. A statistically significant relationship between age and genital hygiene behaviors of pregnant women was identified $(p<0.05)$. Average marriage year of pregnant women in rural regions was 4.96 $\pm 4.48(1-25)$ and those in urban regions had an average marriage year of $5.79 \pm 4.76(1-22)$. Average marriage years of pregnant women created a difference in their genital hygiene behaviors ( $p<0.05$; Table 1$)$.

When obstetric features of pregnant women were examined, it was identified that $93.5 \%$ of all pregnant women became pregnant willingly, and 67.6 of pregnant women in rural regions and $80 \%$ of those in urban regions had planned pregnancy. It was calculated that average pregnancy of pregnant women was $32.59 \pm 7.37(8-41)$ in rural regions and 33.45 $\pm 6.02(6-40)$ in urban regions. Obstetric features of pregnant women in both regions were similar and it was found that there was not a statistically significant relationship between their obstetric features and genital hygiene behaviors ( $p>0.05$; Table 2).

In accordance with the living places of pregnant women in study, when their GHBI mean scores were examined, it was calculated that all pregnant women had $79.83 \pm 12.28$, those in rural regions had $77.06 \pm 13.16$ and those in urban regions had $81.59 \pm 11.39$ in GHBI mean scores. It was identified that $\mathrm{GHBI}$ mean scores of pregnant women in urban regions were significantly higher than those living in rural regions $(p<0.05$; Table 3). 
Table 1. Comparison of genital hygiene behaviors of pregnant women in accordance with individual features

\begin{tabular}{|c|c|c|c|c|c|c|}
\hline \multirow{2}{*}{\multicolumn{2}{|c|}{$\begin{array}{l}\text { Individual features } \\
(n=278)\end{array}$}} & Rural ( $n=108)$ & \multicolumn{2}{|c|}{ Urban $(n=170)$} & GHBI & \multirow[t]{2}{*}{ Test and $p$} \\
\hline & & $\mathrm{n}(\%)$ & $\mathrm{n}(\%)$ & & $\overline{\mathbf{X}} \pm \mathrm{SD}$ & \\
\hline \multicolumn{7}{|l|}{ Educational status } \\
\hline Primary school & & $29(26.9)$ & $30(17.6)$ & & $78.16 \pm 11.53$ & \multirow{4}{*}{$\begin{array}{l}K W=4.656 \\
p=0.003^{*}\end{array}$} \\
\hline Secondary school & & $48(44.4)$ & $32(18.8)$ & & $77.20 \pm 12.54$ & \\
\hline High school & & $21(19.4)$ & $55(32.4)$ & & $80.69 \pm 11.79$ & \\
\hline University & & $10(9.3)$ & $53(31.2)$ & & $84.25 \pm 9.38$ & \\
\hline \multicolumn{7}{|l|}{ Working status } \\
\hline Yes & & $13(12.0)$ & $48(28.2)$ & & $83.00 \pm 9.53$ & \multirow{2}{*}{$\begin{array}{l}z=-1.996 \\
p=0.046 * *\end{array}$} \\
\hline No & & $95(88.0)$ & $122(71.8)$ & & $79.12 \pm 12.12$ & \\
\hline \multicolumn{7}{|l|}{ Profession type } \\
\hline Worker & & $5(38.5)$ & $21(43.8)$ & & $83.80 \pm 9.70$ & \multirow{3}{*}{$\begin{array}{l}\mathrm{KW}=0.375 \\
\mathrm{p}=0.689\end{array}$} \\
\hline Officer & & $3(23.1)$ & $9(18.8)$ & & $81.70 \pm 10.29$ & \\
\hline Self-employment & & $5(38.5)$ & $18(37.5)$ & & $84.10 \pm 8.80$ & \\
\hline \multicolumn{7}{|l|}{ Health coverage } \\
\hline Available & & $72(66.7)$ & $143(84.1)$ & & $80.41 \pm 11.18$ & \multirow{2}{*}{$\begin{array}{l}z=-1.262 \\
p=0.208\end{array}$} \\
\hline Unavailable & & $36(33.3)$ & $27(15.9)$ & & $78.22 \pm 13.38$ & \\
\hline \multicolumn{7}{|l|}{ Income status } \\
\hline Lower income than expen & & $44(40.7)$ & $60(35.3)$ & & $79.86 \pm 11.73$ & \multirow{3}{*}{$\begin{array}{l}K W=0.564 \\
p=0.570\end{array}$} \\
\hline Balanced income and exp & ure & $40(37.0)$ & $90(52.9)$ & & $80.49 \pm 11.57$ & \\
\hline Higher income than exper & & $24(22.2)$ & $20(11.8)$ & & $78.23 \pm 12.34$ & \\
\hline \multicolumn{7}{|c|}{ Living place (the longest period of time) } \\
\hline City & & $8(7.4)$ & $89(52.4)$ & & $82.00 \pm 10.69$ & \multirow{3}{*}{$\begin{array}{l}K W=2.451 \\
p=0.088\end{array}$} \\
\hline Town & & $25(23.1)$ & $76(44.7)$ & & $79.64 \pm 11.11$ & \\
\hline Village & & $75(69.4)$ & $5(2.9)$ & & $78.01 \pm 13.17$ & \\
\hline \multicolumn{7}{|l|}{ Genital discharge status } \\
\hline Transparent & & $49(45.4)$ & $74(43.5)$ & & $80.08 \pm 11.24$ & \multirow{10}{*}{$\begin{array}{l}K W=6.853 \\
p=0.652\end{array}$} \\
\hline White & & $17(15.7)$ & $32(18.8)$ & & $81.92 \pm 13.39$ & \\
\hline Smelly, transparent & & $8(7.4)$ & $11(6.5)$ & & $78.42 \pm 10.80$ & \\
\hline Smelly, itchy, white & & $9(8.3)$ & $4(2.4)$ & & $75.62 \pm 12.51$ & \\
\hline Smelly, yellow & & $7(6.5)$ & $13(7.6)$ & & $78.60 \pm 10.96$ & \\
\hline Yellow, itchy & & $4(3.7)$ & $9(5.3)$ & & $79.62 \pm 11.10$ & \\
\hline Transparent, itchy & & $5(4.6)$ & $3(1.8)$ & & $77.63 \pm 11.33$ & \\
\hline Smelly, yellow and painfu & & $3(2.8)$ & $1(0.6)$ & & $83.25 \pm 14.31$ & \\
\hline Smelly, white, painful & & $4(3.7)$ & $6(3.6)$ & & $79.63 \pm 10.74$ & \\
\hline Smelly, yellow, itchy & & $2(1.8)$ & $17(10.0)$ & & $80.78 \pm 10.33$ & \\
\hline \multicolumn{7}{|l|}{ Status of having infection } \\
\hline Yes & $24(23.1)$ & & $46(27.9)$ & & $82.56 \pm 10.20$ & \multirow{2}{*}{$\begin{array}{l}z=-0.468 \\
p=0.640\end{array}$} \\
\hline No & $84(77.8)$ & & $124(72.9)$ & & $80.82 \pm 11.58$ & \\
\hline \multirow[t]{2}{*}{ Mean scores } & $\overline{\mathrm{X}} \pm \mathrm{SD}$ & Min-Max. & $\overline{\mathrm{X}} \pm \mathrm{SD} \quad \mathrm{N}$ & Min.-Max. & $\overline{\mathrm{X}} \pm S D$ & \\
\hline & $n(\%)$ & & $n(\%)$ & & & \\
\hline Age of pregnant women & $26.06 \pm 5.83$ & $18-41$ & $27.86 \pm 5.27$ & $18-40$ & $79.91 \pm 11.75$ & \multirow{3}{*}{$\begin{array}{l}z=-70.921 \\
p=0.008^{*}\end{array}$} \\
\hline $18-25$ & $55(32.4)$ & & $54(50.0)$ & & $77.77 \pm 12.49$ & \\
\hline 26 and higher & $115(67.6)$ & & $54(50.0)$ & & $81.37 \pm 10.98$ & \\
\hline Marriage year & $4.96 \pm 4.48$ & $1-25$ & $5.79 \pm 4.76$ & $1-22$ & $79.99 \pm 11.72$ & \multirow{3}{*}{$\begin{array}{l}z=-98.271 \\
p=0.001\end{array}$} \\
\hline $1-10$ & $23(71.9)$ & & $55(32.4)$ & & $80.65 \pm 9.89$ & \\
\hline 11 and higher & $9(28.1)$ & & $115(67.6)$ & & $82.00 \pm 8.43$ & \\
\hline
\end{tabular}

\%Percentage, $\bar{X} \pm$ SDMeantstandard deviation, nNumber, KWKruskal Wallis Test, ZMann Whitney U Test, pSignificance level, GHBIGenital Hygiene Behavior Inventory, 
Table 2. Comparison of pregnant women's genital hygiene behaviors in terms of their obstetric features

\begin{tabular}{|c|c|c|c|c|c|c|}
\hline \multirow{2}{*}{$\begin{array}{l}\text { Features } \\
(n=278)\end{array}$} & \multicolumn{2}{|c|}{ Rural (n=108) } & \multicolumn{2}{|c|}{ Urban $(n=170)$} & GHBI & \multirow{2}{*}{ Test and p } \\
\hline & \multicolumn{2}{|c|}{$n(\%)$} & \multicolumn{2}{|c|}{$n(\%)$} & \multirow{2}{*}{\multicolumn{2}{|c|}{$\overline{\mathrm{X}} \pm \mathrm{SD}$}} \\
\hline \multicolumn{5}{|c|}{ Status of willingness for pregnancy } & & \\
\hline I wanted. & $101(93.5)$ & & $159(93.5)$ & & $9.94 \pm 11.71$ & \multirow{2}{*}{$\begin{array}{l}z=0.355 \\
p=0.723\end{array}$} \\
\hline I did not want. & $7(6.5)$ & & $11(6.5)$ & & $79.53 \pm 12.32$ & \\
\hline \multicolumn{7}{|c|}{ Status of pregnancy plan } \\
\hline Planned & $73(67.6)$ & & $136(80.0)$ & & $79.97 \pm 12.05$ & \multirow{3}{*}{$\begin{array}{l}z=-1.424 \\
p=0.156\end{array}$} \\
\hline Unplanned & $35(32.4)$ & & $34(20.0)$ & & $79.73 \pm 10.80$ & \\
\hline \multirow{2}{*}{ Mean scores } & $\bar{X} \pm S D$ & Min.-Max. & $\bar{X} \pm S D$ & Min.-Max. & $\bar{X} \pm S D$ & \\
\hline & $n(\%)$ & & $\mathrm{n}(\%)$ & & & \\
\hline Pregnancy number & $2.26 \pm 1.34$ & $1-8$ & $2.27 \pm 1.42$ & $1-7$ & $80.00 \pm 11.76$ & \multirow{4}{*}{$\begin{array}{l}K W=0.644 \\
p=0.725\end{array}$} \\
\hline 1 & $39(36.1)$ & & $71(41.8)$ & & $80.79 \pm 11.03$ & \\
\hline $2-3$ & $51(47.2)$ & & $67(38.4)$ & & $82.55 \pm 10.61$ & \\
\hline 4 and more & $18(16.7)$ & & $32(18.8)$ & & $77.02 \pm 12.97$ & \\
\hline Delivery number & $1.55 \pm 0.98$ & $0-5$ & $1.78 \pm 1.04$ & $0-5$ & $79.35 \pm 12.41$ & \multirow{3}{*}{$\begin{array}{l}z=-0.533 \\
p=0.594\end{array}$} \\
\hline 1 & $38(55.9)$ & & $48(52.2)$ & & $77.14 \pm 12.53$ & \\
\hline 2 and more & $27(39.7)$ & & $39(42.4)$ & & $79.87 \pm 13.52$ & \\
\hline Number of children & $1.52 \pm 0.89$ & $0-5$ & $1.74 \pm 1.04$ & $0-5$ & $79.54 \pm 11.67$ & \multirow{3}{*}{$\begin{array}{l}z=-1.042 \\
p=0.297\end{array}$} \\
\hline 1 & $34(58.6)$ & & $43(50.0)$ & & $82.42 \pm 9.92$ & \\
\hline 2 and more & $24(41.4)$ & & $43(50.0)$ & & $78.67 \pm 13.67$ & \\
\hline Miscarriage number & $1.33 \pm 0.96$ & $0-5$ & $1.33 \pm 0.69$ & $1-4$ & $79.82 \pm 10.38$ & \multirow{3}{*}{$\begin{array}{l}z=-0.297 \\
p=0.767\end{array}$} \\
\hline 1 & $15(62.5)$ & & $25(75.8)$ & & $79.43 \pm 10.77$ & \\
\hline 2 and more & $9(37.5)$ & & $8(24.2)$ & & $80.76 \pm 9.66$ & \\
\hline Number of death & $0.56 \pm 0.53$ & $0-1$ & $1.00 \pm 0.00$ & $1-1$ & $79.79 \pm 1188$ & $z=-0.869$ \\
\hline Available & $5(4.6)$ & & $6(3.5)$ & & $83.00 \pm 8.66$ & $p=0.385$ \\
\hline Unavailable & $103(95.4)$ & & $164(96.5)$ & & $79.66 \pm 11.99$ & \\
\hline Number of abortion & $1.47 \pm 1.30$ & $0-1$ & $1.34 \pm 0.77$ & $0-4$ & $81.39 \pm 10.76$ & $z=-0.275$ \\
\hline 1 & $6(50.0)$ & & $21(72.4)$ & & $79.78 \pm 15.19$ & $p=0.783$ \\
\hline 2 and more & $6(50.0)$ & & $8(27.6)$ & & $82.79 \pm 7.52$ & \\
\hline Pregnancy week & $32.59 \pm 7.37$ & $8-41$ & $33.45 \pm 6.02$ & $6-40$ & $79.96 \pm 11.69$ & \\
\hline The first follow-up & $1.47 \pm 0.88$ & $1-6$ & $1.05 \pm 0.43$ & $1-6$ & $79.91 \pm 11.72$ & \\
\hline
\end{tabular}

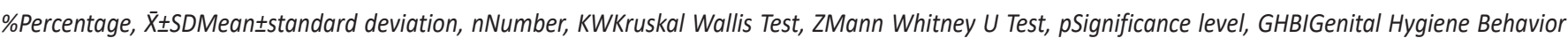
Inventory

Table 3. Comparison of $\mathrm{GHBI}$ mean scores of women in research sample in terms of rural and urban regions

\begin{tabular}{|llll|}
\hline Regions & Pregnant women & GHBI & Test and $\mathbf{p}$ \\
\hline ( $\mathbf{n}=\mathbf{2 7 8})$ & $\mathrm{n}(\%)$ & $\overline{\mathbf{X}} \pm$ SD & \\
\hline Rural & $108(38.85)$ & $77.06 \pm 13.16$ & $\mathrm{z}=-2.864$ \\
\cline { 1 - 3 } Urban & $170(61.15)$ & $81.59 \pm 11.39$ & $\mathrm{p}=\mathbf{0 . 0 0 4 ^ { * }}$ \\
\cline { 1 - 3 } Total & $278(100)$ & $79.83 \pm 12.28$ & \\
\hline
\end{tabular}

\%Percentage, $\bar{X} \pm S D M e a n \pm$ standard deviation, nNumber, ZMann Whitney $U$ Test, pSignificance level, GHBIGenital Hygiene Behavior Inventory

\section{DISCUSSION}

In our research, it was identified that pregnant women, who had an education level at high school and university, genital hygiene behaviors were significantly higher at those having higher levels of education. Similarly, in the study carried out by llgaz et al. (17), it was seen that women in urban regions with better socio-demographic conditions showed more positive genital hygiene behaviors. In another study, it was identified that educational status affected genital hygiene behavior in consistency with our study (18). Likewise, in a study carried out in Cameroon, it was found that sociodemographic features and genital hygiene habits influenced prevalence of bacterial vaginal infections (19). Accordingly, it can be inferred that pregnant women with low level of education are privileged in terms of genital hygiene training.

In this study, it was identified that pregnant women resided mostly in urban regions and working status affected genital hygiene behaviors positively. Similarly, in the study of Şahin Orak and Canuygur (20), it was found that working women had better genital hygiene behaviors in comparison with those who did not work. Çankaya and Ege (21) identified that women who were sexually active and worked had more positive genital hygiene habits than those who did not work. In accordance with these findings, it is thought that working pregnant women reach knowledge about healthy life style and health services more easily due to their economic freedom. In this regard, pregnant women, who have difficulty in reaching health services, and their training requirements should be identified. 
In the current research, it was identified that pregnant women, living in rural and urban regions with higher ages, had significantly higher levels of genital hygiene behaviors in a similar way. In the research done by Masha et al. (22), it was found that age factor was correlated with genital hygiene behaviors. In another study carried out in southeastern Turkey, it was identified that genital hygiene behaviors and age factor affected vaginal infections in women who were seasonal agricultural workers (23). Similarly, in a study where genital hygiene behaviors of girls at adolescence period were investigated, majority of the participants stated that they did not have knowledge about genital hygiene behaviors, and erroneous genital hygiene behaviors were identified (24). According to these results, it is thought that especially young individuals living in rural regions should be privileged in terms of gaining positive behaviors on genital hygiene.

In our research, it was stated that pregnant women living in rural regions were mostly at the first ten years of their marriage and there was a relationship between marriage year and genital hygiene behaviors. In the research of Çankaya and Ege (21), it was calculated that married women had marriage year averages of higher than fifteen years and was found that women, who had genital infection diagnosis, had more negative genital hygiene behaviors. In a similar study, among pregnant women, residing close to two different family health centers, it was stated that those residing in rural regions had earlier first marriage ages than those in urban regions and it was found that those living in urban regions had more positive genital hygiene behaviors (17). In this sense, these results make us think that newly-wed individuals should be informed about genital hygiene behaviors.

In our research, it was identified that pregnant women living in urban regions had more positive genital hygiene behaviors in comparison with those living in rural regions and the difference between genital hygiene mean scores were statistically significant. In the research of Thakur et al. (25), it was determined that women living in rural regions had a weaker level of genital hygiene behaviors. In another study done in eastern Turkey, it was found that women mostly did the practice of vaginal douching and this affected women's health negatively (26). On the other hand, it was seen that women with negative genital hygiene behaviors were more prone to urinary tract infections, genital ulceration, bacterial vaginal infections and cervical cancers $(8,20,22,25)$. In another study carried out systematically, prevalence of vaginal infections at a high rate was noteworthy in pregnant women living in low and middle income countries (27). It is seen that living place of pregnant women is affective on their genital hygiene behaviors and prenatal trainings specific to living places of pregnant women should be planned.

\section{CONCLUSION}

It was seen that living places of pregnant women influenced their genital hygiene. Pregnant women living in urban regions had more positive genital hygiene behaviors when compared with those living in rural regions. In line with these findings, supporting pregnant women living in rural regions by informing them about healthy life behaviors like genital hygiene behaviors gains importance due to their socio-demographic features. Thus, health trainings about genital hygiene behaviors should be a part of school curricula and training programs of health institutions. Additionally, it should be provided that midwives and nurses working at health care areas primarily take charge in active practices more effectively, which can increase awareness levels of pregnant women living in rural areas.

\section{Limitations of the Research}

The findings gained from this research represent pregnant women applying to the hospital for follow-up. Additionally, the research data is limited to the responses of participant pregnant women.

Conflict of interest: There is no conflict of interest among the authors to declare.

\section{REFERENCES}

[1] Arslan H, Kömürcü N, Yıldız Eryılmaz $H$, Gençalp NS, Engin Yiğit F, Ekşi Z, Can Gürkan Ö, Coşkuner Potur D, Ek Sayın D, Çıtak Bilgin N. Üreme sağlığı bilinci geliştirme projesi. Genital Akıntılar. HEAD 2008;5(1):34-40. (Turkish)

[2] Temel M, Metinoğlu M. Tekirdağ iline bağlı I. ve IV. nolu sağlık ocaklarına başvuran 15-49 yaş kadınlarda genital hijyen uygulamalarının incelenmesi. FNJN 2007;5:91-99. (Turkish)

[3] Bahram A, Hamid B, Zohre T. Prevalence of bacterial vaginosis and impact of genital hygiene practices in non-pregnant women in Zanjan, Iran. Oman Med J 2009; 24(4):288-293.

[4] Yağmur Y. Malatya ili Fırat Sağlık Ocağı Bölgesi'nde yaşayan 15-49 yaş kadınların genital hijyen davranışları. TSK Koruyucu Hekimlik Bülteni 2007;6(5):325-330. (Turkish)

[5] Taşkın L. Doğum ve Kadın Sağlığı Hemşireliği, 15. baskı. Ankara: Akademisyen Kitapevi; 2016. (Turkish)

[6] Faure E, Faure K, Figeac M, Kipnis E, Grandjean T, Dubucquoi S, Villenet C, Grandbastien B, Brabant G, Subtil D, Dessein R. Vaginal mucosal homeostatic response may determine pregnancy outcome in women with bacterial vaginosis. Medicine (Baltimore) 2016;95(5):2668.

[7] Han C, Li H, Han L, Wang C, Yan Y, Qi W, Fan A, Wang Y, Xue F. Aerobic vaginitis in late pregnancy and outcomes of pregnancy. Eur J Microbiol Infect Dis 2019;38(2):233-239.

[8] Badran YA, El-Kashef TA, Abdelaziz AS, Ali MM. Impact of genital hygiene and sexual activity on urinary tract infection during pregnancy. Urol Ann 2015;7(4):478-481.

[9] Giraldo PC, Amaral RLG, Juliato C, Eleutério J, Brolazo E, Gonçalves AKS. The effect of "breathable" panty liners on the female lower genital tract. Int J Gynecol Obstet 2011; 115:11164.

[10] Pontes AC, Amaral RLG, Giraldo PC, Beghini J, Giraldo HPD, Cordeiro ES. A systematic review of the effect of daily panty liner use on the vulvovaginal environment. Int J Gynecol Obstet 2014; 127:1-5.

[11] Demba E, Morison L, van der Loeff MS, Awasana AA, Gooding $E$, Bailey R, Mayaud P, West B. Bacterial vaginosis, vaginal flora patterns and vaginal hygiene practices in patients presenting 
with vaginal discharge syndrome in The Gambia, West Africa. BMC Infect Dis 2005;5(12):1-12.

[12] Aslan E, Bechelaghem N. To 'douche' or not to 'douche': hygiene habits may have detrimental effects on vaginalmicrobiota. J Obstet Gynaecol 2018;38(5):678-681.

[13] Kahyaoğlu Süt H. 18-49 yaş arası kadınlarda genital hijyen davranışları ile genital enfeksiyon arasındaki ilişkinin incelenmesi. DÜ Sağlık Bil Enst Derg 2016;6(1):8-1. (Turkish)

[14] Topatan S, Demirci N. The efficiency of reproduction health education given to adolescents during the postpartum period. J Pediatr Adolesc Gynecol 2015;28(5):1-7.

[15] Ege E, Eryılmaz G. Kadınlara verilen planlı eğitimin genital hijyen davranışlarına etkisi. J Anatol Nurs Health Sci 2006;9(3):8-16. (Turkish)

[16] Ege E, Eryılmaz G. Genital Hijyen Davranışları Envanteri'nin (GHDE) geliştirilmesi. A.Ü. Hemşirelik Yüksekokulu Dergisi 2005;8(3):67-75. (Turkish)

[17] Ilgaz A, Sevinç Ö, Uzun SU. Íki farklı aile sağlığı merkezinde kayıtlı doğurgan çağdaki evli kadınların genital hijyen davranışları. TAF Preventive Medicine Bulletin 2015;14(2):153160. (Turkish)

[18] Kavak O, Saruhan A, Er S, Şen E, Sevil Ü. Gebelerin genital hijyen davranışlarının belirlenmesi. E.Ü. Hemşirelik Yüksek Okulu Dergisi 2010;26(1):53-63.

[19] Kamga YM, Ngunde JP, Akoachere JKT. Prevalence of bacterial vaginosis and associated risk factors in pregnant women receiving antenatal care at the Kumba Health District (KHD), Cameroon. BMC Pregnancy Childbirth 2019;19(1):166.
[20] Sahin Orak N, Canuygur A. Jinekoloji kliniğinde yatan hastaların genital hijyen davranışlarının incelenmesi. Balikesir Sağlık Bil Derg 2014;3(3):130-134. (Turkish)

[21] Çankaya S, Ege E. Evli kadınların genital hijyen davranışlarının ürogenital semptomlar ile ilişkisi. Türkiye Klinikleri J Nurs Sci 2014;6(2):94-101. (Turkish)

[22] Masha SC, Wahome E, Vaneechoutte M, Cools P, Crucitti T, Sanders E. High prevalence of curable sexually transmitted infections among pregnant women in a rural county hospital in Kilifi, Kenya. PLoS One 2017;12(3):e0175166.

[23] Yağmur Y, Orhan Ergin I. Mevsimlik tarım işçisi kadınların yaşam koșulları ve genital hijyen uygulamaları. J Int Soc Araştırmalar Res 2017;10(51):614-620.

[24] Yılmaz Y, Kahraman S. Şanlıurfa'da Adölesan dönemde kızların genital bölge ve hijyeni ile ilgili bilgi, uygulamaları ve etkileyen faktörler. İnt J H Sci 2019;16(3):823-832. (Turkish)

[25] Thakur A, Gupta B, Gupta A, Chauhan R. Risk factors for cancer cervix among rural women of a hilly state: A case-control study. Indian J Public Health 2015;59(1):45-48.

[26] Ege E, Timur S, Zincir H, Eğri M, Sunar Reeder B. Women's douching practices and related attitudes in eastern Turkey. J Obstet Gynaecol Res 2007;33(3):353-359.

[27] Joseph Davey DL, Shull HI, Billings JD, Wang D, Adachi $\mathrm{K}$, Klausner JD. Prevalence of curable sexually transmitted infections in pregnant women in low and middleincome countries from 2010 to 2015: A systematic review. Sex Transm Dis 2016;43(7):450-458. 